\title{
Compounds and multi-word expressions in Russian
}

\section{Introduction}

This chapter deals with the discussion of the relation between multi-word expressions, compounds, and derivations in the description of Russian and other Slavic languages. Referring to pertinent publications, the aim is to show how these descriptions have been influenced by particular theoretical conceptions (e.g. the onomasiological view adopted by Dokulil 1962) and the respective grammatical tradition (e.g. Russkaja grammatika 1980, generally known as "Grammatika-80": Švedova 1980). New approaches to the description of the relation between phrases and derivatives as well as between phrases and a special type of Russian compounds (the so-called stump compounds) from the viewpoint of Construction Grammar are presented with reference to works by Benigni/Masini (2010) and Masini/Benigni (2012). In view of recent linguistic developments, the competition between multi-word expressions and $\mathrm{N}+\mathrm{N}$ compounds is discussed, which persists irrespective of the increasing productivity of this compound type in Russian.

The chapter does not provide a comprehensive overview of all naming processes in Russian, but rather focuses - also from the perspective of research history - on those types of nominal multi-word expressions and compounds (as well as one derivational type) that stand in a mutual relation of cooperation and/or competition. Particular attention will be paid to stylistic and pragmatic aspects.

The chapter is organized as follows: Section 1 gives a brief overview of the main findings of previous studies on complex lexical units in Russian and other Slavic languages. Section 2 presents compound and MWE patterns in Russian as well as their interrelation as discussed in Grammatika-80. Sections 3 and 4 discuss the co-existence and interaction between MWEs and various morphological patterns. The chapter ends with a conclusion in Section 5.

\section{Some remarks on the current state of research}

The interaction of various naming procedures in Slavic languages has been discussed from different angles. 


\section{1 "Condensation" of complex naming units}

Isačenko (1958), for instance, paid special attention to the formal and semantic condensation of complex naming units, stating that "complex designations consisting of several lexical units have a clear tendency towards univerbation, i.e. to the compression of the semantic content into one word" (ibid.: 340; translated from Russian). This phenomenon manifests itself in different naming procedures:

a) Certain types of compounding (e.g., Slovak svet-o-názor [world.Lv o-view] ${ }^{1}$ 'world view' < svetový názor [world.RA view] 'id. '2,3)

b) Mergers (Czech pravdè-podobný [truth.DAT-similar] 'probable')

c) Ellipsis

1) of the head (Russian prjamaja 'straight line' < prjamaja linija 'id.')

2) of the modifier (Russian plastinka 'record' < grammofonnaja plastinka '(grammophone) record')

d) Affixal derivation (Russian setčat-k-a 'retina' < setčataja oboločka [net.A membrane] 'id.')

e) Binominals (appositional compounds), particularly in Russian, e.g., ženščina-vrač [woman-doctor] 'female doctor'

f) Different types of compounds with a clipped modifier ("stump compounds" in the terminology of Comrie/Stone 1978 and Comrie/Stone/Polinsky 1996) (Russian zarplata 'salary'< zarabotnaja plata [for.work.RA payment] 'id.'), but also of initialisms and acronyms (Russian IMLI < Institut mirovoj literatury [institute world.RA.GEN literature.GEN] 'Institute of World Literature' [of the Russian Academy of Sciences]). According to Isačenko, the dominance of this latter type in Russian is not accidental as it provides an important option to condensate MWEs with modifiers in the genitive case.

g) Formations of the type Russian Glavryba [glav- clipped stem of the adjective glavnyj 'main, principal' + ryba 'fish'] < Glavnoe upravlenie rybnoj promyšlennost $i$ - the name of the Soviet central administration of the fishing industry. As has been pointed out by one of the reviewers, from a semantic point of view, Glavryba reflects a metonymic shift, because the modifier does not directly modify the noun, but a concept connected to the noun ("central

$1 \mathrm{LV}$ : linking vowel

2 RA: relational adjective

3 In Czech, the MWE still exists next to the compound (světový názor and světonázor) as an obvious calque of the German Weltanschauung 'id.'. 
administration of the fishing industry"). ${ }^{4}$ In this respect formations like Glavryba differ from stump compounds like glavvrač < glavnyj vrač 'head physician'.

\subsection{MWEs, compounds, and derivations from an onomasiological point of view}

The relationship between MWEs, compounds, and derivations was dealt with in Czech linguistics in the description of word formation as part of naming procedures (Dokulil 1962). Thus for example Czech MWEs, compounds, and suffixed compounds (1a-e) are contrasted with suffixed derivatives (1a'-e') (with the same meaning) (ibid.: 31):

(1a) malíř krajin [painter landscape.PL.GEN] 'landscape painter'

(1b) hráč na housle [player on violin] 'violin player'

(1c) žák první třidy [pupil first.GEN grade.GEN] 'first-grader'

(1d) kov-o-dělník 'metalworker'

(1e) dřev-o-rub-ec 'woodcutter'

(1a') krajin-ár̆

(1b') housl-ista

(1c') prvň-ák

(1d') kov-ák

(1e') dřev-ař

Dokulil (ibid.) uses examples from terminology and technical language to show that the formation of multi-word designations is a very common naming procedure, as in (2):

(2a) $\mathrm{A}+\mathrm{N} \quad$ vysoké napěti 'high voltage'

(2b) $\mathrm{N}+\mathrm{N}_{\mathrm{GEN}} \quad$ stupnice tvrdosti [scale hardness.GEN] 'hardness scale'

In spite of this, such procedures appear "cumbersome" in an inflectional language, which is why single word names are preferred in everyday speech. This can also be seen from the so-called univerbations which - according to the tradi-

4 This formation type can also be found in more recent designations, e.g., Glavlinza [main lens], a leader brand for contact lenses. (www.glavlinza.ru, last access: 1.3.2017). 
tional interpretation of the term in Slavic studies - means the transformation of MWEs into suffixed one-word designations. According to Dokulil, an important criterion of "univerbized" designations is the coexistence of a synonymous multi-word designation (generally of the structure/form RA+N), which should be a real, i. e. a fixed (established) naming unit, but not any free combination of words, e.g.:

$$
\text { čajová růže } e^{5} \text { [tea.RA rose] 'tea rose’ > čajovka tea.RA-stem-SUFF 'id.' }{ }^{9}
$$

The word stař-ik 'old man' should, however, be regarded as a deadjectival suffixed formation < starý 'old' and not as univerbation of starý člověk 'old man'. A significant extension of the concept of univerbation in Slavic studies has been proposed in a new monograph on Slovak (Ološtiak (ed.) 2015). In this study, the criterion of stability of the underlying MWEs is maintained. The results, however, are not restricted to suffix formations. Some examples are provided by Ološtiak (ed.) (ibid.: 308ff.):

(4a) MWEs and "traditional" suffixal univerbations with truncation of the stem and ellipsis of the head, e.g., Slovak izolač-n-á páska 'insulating tape' > izolač- $k-a$ 'id.'

(4b) Combination of compounding and univerbation ("kompozičná univerbizácia”), e.g., Slovak hráč prvej ligy [player first.GEN division.GEN] > prv-o-ligist- $a$ 'first division player'. In Russian grammars, the analog formation pervoligist < pervaja liga is described as suffixed compound

(4c) Clipping of the modifier of an MWE and formation of a compound, e.g. Slovak alkoholový test > alkotest 'alcotest' (however, this formation might also be a direct loan from English)

(4d) Phenomena like the following are also included:

Slovak kompaktný fotoapparát > kompakt 'compact camera'

(4e) The formation of acronyms from MWEs is also often regarded as univerbation:

Slovak Mestská hromadná doprava >MHD; coll. suffixed MHD-čka 'local public transport”

5 In botanical nomenclature N+RA růže čaj-ová [rose tea-RA] 'tea rose' with inverted word order.

6 Another formally identical word can be based on the MWE čajový salám 'tea sausage (spread)'.

7 The vernacular suffixation of acronyms is more productive in Slovak than in Russian. 
For a concise overview of different approaches to univerbation in the Slavic national philologies cf. Martincová (2015).

Kuchař (1963) took up the question of a possible systematic relation among different naming processes. His starting point was the following idea: if word formation is considered as name formation with morphological means, then there might also be similar processes on the syntactic level (i.e. syntactically complex forms) and on the semantic level (i.e. semantic shifts). The aim would then be to discover the common as well as the specific characteristics of the three naming procedures, as for example in Czech hlup-ák (stupid-sufF) 'fool', hloupý člověk 'stupid, foolish person' and osel '[neutral donkey], dope, ass' with the same meaning.

For instance, in Czech causal relations are not realized as denominal verbs but as complex namings, e.g. zemřit hladem (die hunger.INSTR) 'die of hunger, starve', zemř́t žizní 'die of thirst'. Purpose relations are realized as prepositional word combinations (cf. Czech míchačka na beton [mixer for concrete]) 'concrete mixer' in contrast to compounds such as Russian betonmešalka 'id.' and others. ${ }^{8}$ If metaphor, metonymy, and synecdoche are viewed from an onomasiological perspective, similar types of onomasiological structures (according to Kuchař 1963) can be identified, which can be realized either by word formation, by syntactic means, e.g. conjunctions (Czech jak(o) 'like' - jako had 'like a snake') or alternatively by MWEs, expressing for instance similarity as in hadí muž [snake-RA man] 'snake man'. Metonymic shifts can be observed in many deverbal abstract nouns, describing not only the action but also the result. Part-whole relationships can be expressed in Russian by suffixal singulatives (solom-inka [straw-SUFF] 'blade of straw', pesč-inka [dust-SUFF] 'mote of dust'), contrasting with combinations $\mathrm{N}+\mathrm{N}_{\mathrm{GEN}}$ in Czech (stéblo slámy [blade straw.GEN], zrnko písku [grain.DIM dust.GEN]).

\section{Compounds and MWEs in Russian}

This section provides a brief overview of compound and MWE patterns in Russian. We specifically focus on the question if and to what extent the relation between these two naming procedures is being paid attention to in Russian grammars.

8 For similar examples in Polish cf. Cetnarowska (this volume). 


\subsection{Compounds}

We start with the classification of nominal compounds as provided by Grammatika-80 (Švedova 1980: 242ff.). This grammar distinguishes between two groups (cf. A and B in Table 1). ${ }^{9}$

Table 1: Patterns of Russian nominal compounds

\section{A. Coordinate nominal compounds}

1. $\mathrm{N}+\mathrm{LV}+\mathrm{N}$

Formations of this group are rather rare, e.g. lesostep' 'forest steppe'.

2. $\mathrm{N}+\mathrm{N}$ (with hyphenated spelling)

In Grammatika-80 (Švedova 1980: 253) some formations of this type are still regarded as word combinations whose first component is no longer subject to declination, e.g. divan krovat' 'sofa bed'. ${ }^{10}$

\section{B. Subordinate nominal compounds}

1. $\mathrm{N}_{\text {STEM }}+\mathrm{LV}+\mathrm{N}^{11}$

zvuk-o-režisser 'sound editor', sen-o-uborka 'hayharvest' (cf. Section 4.2.1)

2. $\mathrm{N}+\mathrm{N}$

Focussing on the absence of a linking vowel, Grammatika-80 forms a heterogeneous group of formations, including loans such as džaz-orkestr 'jazz orchestra'. On the activation of the $\mathrm{N}+\mathrm{N}$ type cf. Section 4.2.2.

9 Attributive compounds are not considered as a group in their own right, cf. however Benigni/ Masini (2009).

10 Some formations of this structure are not considered as compounds, but as appositive constructions and thus as syntactic phenomena, cf. car'-ubijca [tsar-murderer] 'a tsar who was a murderer' (in contrast to the determinative compound careubijca [tsar.Lv.murderer] 'regicide'). Cf. also inžener-fizik [engineer-physicist] 'engineer and physicist'; sudno-cholodil'nik [ship-refrigerator] 'refrigerator ship'; more recent: komp'juter-tabletka 'tablet computer'.

The combination of two words is not considered appositive if they designate objects consisting of a larger number of elements or groups of persons and semantically resemble a single word. In Russian they are frequently used as a means of stylization, e.g., čaški-bljudca [cups-plates] 'dishes', ruki-nogi [hands-legs] 'limbs', devočki-mal'čiki [girls-boys] 'children' (cf. also Wälchli 2015, who uses the term "co-compound" for similar, but regular and stylistically neutral formations in various languages).

11 The lack of compounds with (de-)verbal modifiers is often compensated by phrases of the structure $[\mathrm{A}<\mathrm{V}]+\mathrm{N}$ (e.g., stiral'naja mašina 'washing machine'). Compare, however, some types of exocentric compounds, whose first constituent might be regarded as derived from an imperative, as in sorvigolova [bite-off-head] 'daredevil'. 


\section{B. Subordinate nominal compounds}

3. Frequent first components (modifiers) $+\mathrm{N}$

a. samo- 'self-' samoocenka 'self-assessment'

b. vzaimo- 'inter-, mutual' vzaimopomošč 'mutual aid'

c. lže-(<lož' 'lie') 'pseudo-' lženauka 'pseudoscience'

d. polu-/pol- 'half-' polukrug 'semicircle', polčasa 'half an hour'

e. Some formations with hyphenated spelling, čudo-bogatyr' '(epic) hero with magical also known from folk literature, e.g., čudo- stength', 'miracle, wonder' or gore- 'sorrow, misery' gore-rukovoditel 'bad leader, manager'

4. Clipped stems of nouns and/or adjectives (mostly internationalisms) as modifier $+\mathrm{N}$ avto $_{1}$ (referring to avtomobil' 'car' and RA avtotransport 'mototransport', avtovokzal avtomobil'nyj; avtobus 'bus'/RA avtobusnyj) (bus terminal'

$a \operatorname{lto}_{2}$ - (referring to avtomatičeskij 'auto- avtokormuška 'automatic feeder' matic')

benzo- (referring to benzin 'petrol') benzozapravka 'filling station' (next to the compound without clipped modifier benzin-o-zapravka 'id'.)

others: kosmo- 'cosmic, referring to astro- kosmoplavanie 'space flight', motolodka nautics', moto- 'referring to motors; motor- 'motorboat', ènergosnabženie 'energy ized', ènergo- 'energy-; energetic', etc. supply'

5. Compounds with bound (mostly neoclassical) modifiers $+\mathrm{N}$

avto $_{3}$-'self-', aero- 'air-', video-, geo-,

gidro- 'hydro-', nevro- 'neuro-', poli- 'poly-',

etc.

6. Compounds with bound (mostly neoclassical) heads

-graf '-grapher', -fil '-phile', -fob '-phobe',

-metr'-meter', etc.

and -logija '-logy', -fobija '-phobia',

-fil'stvo '-philia', etc.

7. Suffixed compound nouns

a. $\left[\left[\mathrm{N} / \mathrm{A}_{\text {STEM }}+\mathrm{V}_{\text {STEM }}\right] \mathrm{SUFF}\right]$

zakonodatel' [[law.Lv.giv]er] 'legislator' lesopil'nja [[wood.Lv.saw]suff] 'sawmill' čaepitie [[tea.Lv.drink]suff] 'tea drinking' (N)

b. $\left[\left[\mathrm{A} / \mathrm{Num}_{\mathrm{STEM}}+\mathrm{N}_{\text {STEM }}\right] \mathrm{SUFF}\right]$ 


\section{B. Subordinate nominal compounds}

8. Compounds with "zero suffixes"12

ékskursovod 'tourist guide', pticevod

$\left[\mathrm{N}_{\text {STEM }}+\mathrm{LV}+\mathrm{STEM} \mathrm{C}_{\varnothing}\right]$

'poultry farmer';

-vod '1. guide; 2 . breeder, 3. grower', -mer

'meter', -provod 'conduit', etc.

\subsection{Multi-word expressions}

In Russian linguistics, the description of (non-idiomatic) subordinate word combinations of different structures, based on

a) agreement (nov-aja kniga [new.FEM book.FEM])

b) government (čitat' knigu [read book.ACc]; urok čtenija [lesson reading.GEN] 'reading instruction'; kniga dlja detej [book for children.GEN 'children's book')

c) adjunction (čitat' vsluch 'to read aloud')

has traditionally been regarded as a domain of syntax.

Following Vinogradov's maxims, coordinate word combinations are ignored in Grammatika-80 (Švedova 1980) while they are taken into consideration in other contributions (e.g. Belošapkova (ed.) 1989 and others).

Fixed subordinate multi-word expressions are described as an object of phraseological research. The distinction of three groups of phrasemes, depending on the degree of idiomatization, goes also back to Vinogradov (1946):

(5a) Phraseological fusions (Russian frazeologičeskie sraščenija) - demotivated opaque idioms, e.g.,

bit bakluši [split logs for the production of wooden household utensils] 'twiddle one's thumbs'

(5b) Phraseological unities (Russian frazeologičeskie edinstva) - partially metaphorically motivated, e.g., plyt' po tečeniju 'go [Russian swim] with the flow'

New calques based on metaphorical motivation are also regarded as phrasemes, e.g.,

12 This type demonstrates once again the wide-spread distribution of compounds with a deverbal second component. Further, less productive formation types are not discussed here. 
myl'naja opera [soap.RA opera] 'soap opera', promyvanie mozgov [washing brain.GEN] 'brainwash'13

(5c) Phraseological word combinations (Russian frazeologičeskie sočetanija), e.g., skoropostižnaja smert' 'sudden death'. The adjective is exclusively combined with designations of death - Russian smert', končina, but *skoropostižnyj ot"ezd [sudden departure]

Phrasemes of the type (5a) and (5b) or their constituents can function as the basis of compounds or derivations, cf., e.g., baklušničat' as synonymous expression to bit' bakluši (5a) or the adjective myl'noopernyi 'similar to a soap opera' < myl'naja opera (5b). Numerous studies are devoted to the relations between phraseology and word formation, including a dictionary of Russian dephrasemic lexis (Alekseenko/Belousova/Litvinnikova (eds.) 2003).

Phrasemes with coordinate relations between the components are generally disregarded in the literature - as in the case of free word combinations (cf. however Benigni (2012: 5f.) on fixed coordinate phrases (binomi coordinativi) with a varying degree of idiomaticity, e.g. mužčina $i$ ženščina 'man and woman', sploš $i$ rjadom [pretty often and nearby] 'very often', ni ryba ni mjaso [neither fish nor flesh] 'neither fish nor fowl').

In continuation of Vinogradov's classification of phrasemes Šanskij ([1963] 1985) specifies a fourth group which proves to be of special importance for our topic:

(5d) Phraseological expressions (Russian frazeologičeskie vyraženija)

Just as the phrasemes of the other groups, they display the following characteristics: multi-word structure, reproducibility, fixedness (and thus belonging to the lexicon). They do not necessarily need to be idiomatic or metaphorical, however, cf., e.g., medicinskaja sestra [medical sister] 'nurse', teplovaja énergija [heat.RA energy] 'heat energy, thermal energy', vyš̌ee učebnoe zavedenie [higher educational institution] 'institution of higher education', etc.

In recent Russian studies (cf. Droga 2010, for instance) such expressions are described as "complex designations" (Russian sostavnye naimenovanija), particularly those of the structure:

13 Cf. Mokijenko/Walter (2008: 105); the authors do however not adopt the traditional typology of phraseology. 
(6a) $\mathrm{A}+\mathrm{N}$

panelnyj dom [panel.RA house] 'panel house, prefabricated building'

(6b) $\mathrm{N}+\mathrm{N}_{\mathrm{GEN}}$ (or - more rarely - other oblique cases)

sredstva massovoj informacii [media mass.RA.GEN information.GEN] 'mass media'

(6c) $\mathrm{N}+$ Prep $+\mathrm{N}$

kniga dlja čtenija [book for reading] 'reader'

It should be mentioned here that such word combinations for a large part compensate for non-existent compound patterns in Russian, including the adaptation of compound loanwords (cf. Section 4). Complex designations of this kind are regarded as "phrasal nouns” by Masini/Benigni (2012: 422): Just like compounds they "generally cannot (a) be interrupted by lexical material, (b) undergo paradigmatic commutability, (c) be internally modified”.

\subsection{The interaction between different naming procedures in Russian academic grammars}

According to Grammatika-80 (Švedova 1980), relations between certain word formation procedures (derivation, compounding) and MWEs only exist if an MWE forms the semantic basis of the word formation (from a formal point of view it is sufficient if only the stem of one constituent of the MWE is retained), e.g.:

(7a) MWE > suffixed one-word combinations, e.g., večernjaja gazeta [evening.RA newspaper] 'evening newspaper' > večer-ka 'id.' (cf. Section 3.1)

(7b) MWE > compounds with clipped modifiers (very often internationalisms) benzinovaja pila > benzopila 'power saw'

(7c) MWE > compounds with neoclassical constituents èkologičeskaja sistema 'ecological system' > èkosistema 'id.'

(7d) Suffixed compounds (synthetic compounds) ${ }^{14}$ $\left[\left[\mathrm{N}_{\text {STEM }}+\mathrm{V}_{\text {STEM }}\right]-\mathrm{SUFF}\right]$ Nouns: kanatochod-ec [[rope.LV.go]-SUFF] 'ropedancer; new: tightrope

14 "Complex words that contain at least three morphemes, with neither the combination of the first two nor of the last two existing as free words" (Neef 2015: 583); other studies use the term "parasynthetic compound". 
walker' < chodit' po kanatu 'to walk on a wire' (in a certain way this also refers to -vod, -mer formations)

$[[\mathrm{A}+\mathrm{N}]-\mathrm{SUFF}]$

nouns: vodolyž-nik [[water.LV.ski]-SUFF] 'water skier' < vodnye lyži

'waterski';

adjectives: dal'nevostoč-nyj [[far.LV.east]-suFF] 'Far Eastern' < Dal'nij

vostok 'Far East'; with alternation $\mathrm{k}>\check{c}$; qualitative adjectives < free word-combinations, e.g., dlinnonogij [[long.Lv.leg]-SUFF] 'long-legged' < dlinnye nogi 'long legs';

(7e) MWE > abbreviations

In Grammatika-80 formations of clipped components of MWEs are regarded as abbreviations, ${ }^{15}$ e.g., prodmag < prodovol'stvennyj magazin [food.RA store] 'food store', etc. (cf. Section 3.2)

Synonymous word formations in the strict sense are listed systematically only for derivations in Grammatika-80 (e.g., salat-nik/salat-nica 'salad dish', žad-ina/ žad-juga 'greedy person', meri-l'nyj/meri-tel'nyj 'measuring', akcentovat'/akcentovirat' 'accent, emphasize', kratk-o/v-kratc-e 'briefly in short'). Regarding adjectival compounds, reference is made to synonymous second components expressing similarity such as -vidnyj,-obraznyj (šarovidnyj, šaroobraznyj [globe/ball.Lv. shaped] 'globular, round'). However, Grammatika-80 does not take into account parallel formations of MWEs and nominal compounds, cf. (8), as they are also found in Polish (cf. Cetnarowska, this volume, example (25)):

(8a) vlag-o-mer [wetness (in Russian non-derived) measure- $\varnothing$ ] 'hygrometer'

(8b) gigro- $\underline{\text { metr }}$ 'id.'

(8c) izmeritel' (sometimes meritel') vlažnosti [measurer wetness.GEN] (alongside rarer forms: izmeritel' vlagi 'id.')

Both in Russian and in Polish (cf. example (26) in the chapter on Polish) the genitive attribute can in turn be modified by another genitive, e.g., izmeritel' vlažnosti vozducha [meter humidity.GEN air.GEN) 'air humidity meter'

The next section discusses phenomena like those in (7a) and (7e) above in greater detail.

15 Masini/Benigni (2009) regard them as compounds. 


\section{Interaction between different naming procedures}

\subsection{MWEs and derivatives}

Derivations like the above-mentioned večerka are regarded as "synonyms" of MWEs in Grammatika-80 (Švedova 1980: 167ff.). ${ }^{16}$ (See, however, below for wellfounded objections against this claim.) Formations with the suffix $-k a$ (fem.) and its variants are the most frequent, as well as masculine suffixes such as -nik, -jak (masc.), as in (9):

(9a) parusnoe sudno [sail.RA boat] 'sailing boat' > parus-nik 'id.'

(9b) tovarnyj poezd [goods.RA train] 'freighttrain' > tovarn-jak 'id.'

According to Masini/Benigni (2012: 421), the MWEs the derivations are based on are "phrasal lexemes which have a naming function", e.g. kreditnaja karta [credit-RA card] 'credit card'. This means that the strategy at hand "consists in shortening a phrasal noun of the [ADJ N] type via ellipsis of the noun plus truncation of the adjective by means of a set of suffixes" (ibid.: 431 ). ${ }^{17}$ They propose the following formal representation of the Russian [ADJ N] lexical construction (ibid.: 444, example (47)):

(10) FORM: $\quad\left[[a]_{\mathrm{Adj}_{\mathrm{X}} \mathrm{O}_{\mathrm{X}}}[b]_{\mathrm{N}^{0} \mathrm{y}}\right]_{\mathrm{N}^{\prime} \mathrm{z}}$ MEANING: <NAME for $\operatorname{SEM}_{\mathrm{y}}$ with the property $\left.\operatorname{SEM}_{\mathrm{x}}\left(\& \mathrm{SEM}_{\mathrm{w}}\right)\right\rangle_{\mathrm{z}}$

For phrasal nouns such as Polish telefon komórkowy [phone cellular] ${ }^{18}$ 'mobile phone', Cetnarowska (this volume, example (31)) proposes the following representation:

$$
\left[\mathrm{N}_{\mathrm{i}}^{0} \mathrm{~A}^{0}{ }_{\mathrm{j}}\right]_{\mathrm{k}} \leftrightarrow\left[\mathrm{NAME} \text { for } \mathrm{SEM}_{\mathrm{i}} \text { with some relation R to entity } \mathrm{E} \text { of } \mathrm{SEM}_{\mathrm{j}}\right]_{\mathrm{k}}
$$

16 Derivations that are not synonymous to MWEs are, for instance, neotlož-ka 'ambulance' < neotložnaja pomošč' [unpostponable aid] 'emergency service', jader-ščik 'nuclear physicist' < jadernaja fizika 'nuclear physics', figure-ist 'figure skater' < figurnoe katanie [figure-RA skating] 'figure skating'.

17 See above for the definition of the term "univerbation" in Slavic studies that does not explicitly mention the ellipsis of the head of the MWE.

18 The postposition of the RA typically applies to phrasal nouns in Polish, i.e. word combinations with a naming function. 
As in other Slavic languages, this shortening process is very productive in Russian and typical of colloquial language. For this reason, such formations are rarely found in dictionaries (cf. ibid.: 434). This is, however, not quite true in the case of neologism dictionaries such as Uluchanov/Belentschikow (2007), which contains numerous derivations of phrasal nouns. The dictionary also contains (then new) MWEs that did not yet include single word formations. Thus, it can be used as a basis for determining registered single word neologisms. A new source is provided by the German-Russian dictionary of neologisms by Steffens/Nikitina (2014).

Most publications address the assignment of the formations to certain thematic areas. Traditionally, and constantly extended with neologisms (see our examples below), these comprise designations of:

(12a) medicines, cosmetics: (new) kompaktka < kompaktnaja gruntovka 'compact foundation'

(12b) pieces of clothing, etc.: futzalki < futzal'naja obuv'/futzal'nye tufli 'shoes for indoor football'

(12c) means of transport and related items: beskontaktka < beskontaktnaja mojka 'touchless car wash'

(12d) public facilities: mnogozalka < mnogozalnyj [multi.hall.RA], kinoteatr 'multiplex (cinema)', etc.

(12e) Numerous neologisms belong to professional and group jargon: in medicine: preimplantacionka < pre-implantacionnaja genetičeskaja dignostika 'preimplantation genetic diagnosis (PGD or PIGD)', or

(12f) in computational language, electronics, e.g., sensorka < sensornyj èkran 'touch screen' and sensornaja igra 'sensor game'

The wide semantic range of the underlying relational adjective results in the occurrence of numerous homonyms, which are disambiguated in the context or the respective communicative situation; elektronka, for instance, can refer to 1. èlektronnaja kniga 'e-book' or 2. èlektronnaja literatura 'e-literature', but also to 3. èlektronnaja sigareta 'electronic cigarette'.

Ološtiak (2015: 296) summarizes typical features, distinguishing Slovak MWEs and the results of "univerbation", as follows:

a) greater vs. lesser degree of formal explicitness and therefore

b) lack of ambiguity vs. greater degree of ambiguity,

c) lack of stylistic markedness vs. markedness,

d) official vs. unofficial character,

e) more pronounced association of MWEs with written language vs. underrepresentation of univerbation in written language. 
Similarly, Masini/Benigni (2012: 441) state that Russian shortened lexemes with $-k a$, "despite having the same propositional meaning of corresponding full forms, have different pragmatic features". These features are implemented in the formal representation of the $-k a$ construction in (13) (cf. ibid.: 445, example 48). The features of the - $k a$ lexemes are compared to those described for diminutives with $-k a$ which also display familiar/intimate characteristics. (Diminutives may, however, also imply negative or ironic traits, cf. Nagórko 2014: 784 on “quasi-diminutives").

$$
\begin{array}{ll}
\text { FORM: } & {\left[[c]_{\mathrm{N}^{\prime}}-k a\right]_{\mathrm{N}_{\mathrm{k}}} \text { where } \mathrm{SYN}_{\mathrm{z}}=\left[[a]_{\mathrm{Adj}_{\mathrm{x}} \mathrm{O}_{\mathrm{x}}}[b]_{\mathrm{N}^{0} \mathrm{y}}\right]_{\mathrm{N}^{\prime} \mathrm{z}} \& \mathrm{PHON}_{\mathrm{z}}} \\
& =\text { truncated ADJ } \\
\text { MEANING: } & <\text { NAME for SEM } \&[+ \text { familiar/intimate }](\&[+ \text { jargon }]])\rangle_{\mathrm{k}}
\end{array}
$$

Thus, although the full forms (the phrasal nouns) and the shortened lexemes in - $k a$ share the semantics, they differ with the respect to their pragmatic and textual properties and thus the formal difference between the constructions comes along with a difference in meaning. For this reason, they are not (fully) synonymous and they meet the non-synonymy constraint on constructions as proposed in Construction Grammar (cf. Masini/Benigni 2012: 446).

With respect to analogous forms in Polish Cetnarowska (this volume) states: "The interaction between phrasal lexemes and derivatives (or compounds proper), exemplified by univerbation, can be accounted for in Construction Morphology by means of second order schemas." The respective representation of "shortened phrasal nouns" in Polish can be found in (14) (cf. Cetnarowska, this volume, example (37)):

(14a) Polish Szkoła budowlana [school building.RA] 'secondary technical school of building' > budowlan-ka

(14b) $\left[\mathrm{N}_{\mathrm{i}}^{0} \mathrm{~A}_{\mathrm{j}}^{0}\right]_{\mathrm{k}} \leftrightarrow$ [NAME for $\mathrm{SEM}_{\mathrm{i}}$ with some relation $\mathrm{R}$ to entity $\mathrm{E}$ of $\left.\mathrm{SEM}_{\mathrm{j}}\right]_{\mathrm{k}}>\approx[\mathrm{A}-k a]_{\mathrm{Nz}} \leftrightarrow\left[\mathrm{SEM}_{\mathrm{k}}[+ \text { familiar }]\right]_{\mathrm{z}}$

\subsection{MWEs/phrases and stump compounds}

Relations between MWEs and one-word designations do not only exist in the area of derivation but also with compounding. This includes formations which in Russian research are frequently described as složnosokraščennye slova ('stump compounds') as they represent a combination of compounding and shortening. The shortening process is not based on morphemes but on syllables, in contrast to compounds with clipped, mostly "neoclassical" modifiers, cf. Section 2.1. Stump 
compounds have become productive since the end of the $19^{\text {th }}$ century and the beginning of the $20^{\text {th }}$ century and are frequently associated with Sovietisms, cf. (15):

(15a) likbez < likvidacija bezgramotnosti $\left(\mathrm{N}+\mathrm{N}_{\mathrm{GEN}}\right)$ 'liquidation of illiteracy' (in the 1920s),

komdiv < komandir divizii (Soviet military rank 1935-1940) 'divisional commander'

(15b) kolchoz< kollektivnoe chozjajstvo $(\mathrm{RA}+\mathrm{N})$ 'collective farm'.

Numerous formations have now become historical formations but lexical units based on these models can still be observed. New formations show a tendency to shorten the modifying components. Formations that contain stumps of both components are often proper nouns, e.g. names of Internet domains:

(16) Dobro požalovat' na oficial'nyj sajt sportivnogo magazina (sport.RA.GEN shop.Gen) Sportmag. ${ }^{19}$

'Welcome to the official site of the sports shop Sportmag'.

\subsection{1 $\mathbf{N}+\mathbf{N}_{\text {GEN }} / \mathbf{N}+\mathbf{N}_{\text {INSTR }}$ as underlying MWEs/phrases}

Stump compounds consisting of two clipped elements are for instance found in the case of the semi-official namings/names of ministries (17a). The stump mincombined with the full form of the genitive is relatively rare (17b). The formation of the stump obor (from oborony) does obviously not comply with the preferred number of syllables (for the phonetic idiosyncracies of the first component of stump compounds cf. Billings 1998). Nevertheless, among the new formations of the type min-+ $\mathrm{N}_{\mathrm{GEN}}$ there is a combination with the non-euphonic stump obr (however not in final position) (17c):

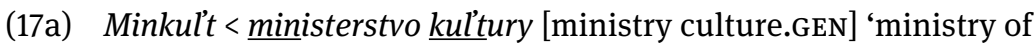
culture', etc.

(17b) Minoborony < Ministerstvo oborony 'ministry of defence'

(17c) Minobrnauki < Ministerstvo obrazovanija i nauki [ministry education.GEN and science.GEN] 'Ministry of education and science'

19 This formation is viewed as an appellative in Acordia/Montermini (2013). 
The genitive ending of the nominal modifier is also retained in some designations of deputies, e.g.:

(18) zampredsedatelja < zamestitel’ predsedatelja ‘deputy chairman' (alongside the older form zampred)

A comparatively small group comprises formations consisting of stumps of nominalized participles (19a, 19b) or a deverbal noun (19c) and the instrumental case of the object (according to the government of the bases - obsolete zavedovat' 'be in charge of', and upravljat' 'manage'):

(19a) zavkafedroj < zavedujuščij kafedroj 'head of the department'

(19b) upravdelami < upravljajuščij delami [manager affairs.INSTR] 'executive officer'20 $^{20}$

(19c) upravdelami < upravlenie delami [administration affairs.INSTR] 'executive office (e.g., of the president, a governor)'

All formations with oblique case forms as second components cannot be inflected. In the adjectival derivation of the type (17b)-(19) which are generally informal, colloquial or ironically connotated, the case ending is clipped, e.g. minoboron-skij gambit 'the gambit of the Ministry of defense', zamdekan-skij post 'position of the vice-dean', or zavkafedr-al'nyj kabinet 'office of the head of the department'.

\subsubsection{Adjectives (mostly relational adjectives) + nouns as underlying MWEs/phrases}

Masini/Benigni (2012: 430) regard this formation type as another "shortening strategy associated with phrasal nouns”, cf. (20):

(20) fizkul'tura < fizičeskaja kul'tura [physical culture] 'physical training, education'

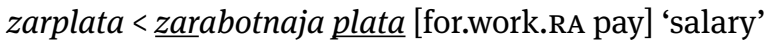

20 See, however, the personal designation upravdom < upravljajuščij domom 'caretaker' where dom is the stump of the instrumental case domom. This formation can be inflected and is easier to use in colloquial language than the formations mentioned above. 
The model is also productive in the formation of neologisms (see below). Compared to the corresponding MWEs/phrases, stump compounds may have the additional advantage of serving as bases for the derivation of relational adjectives, cf.:

sberegatel'nyj bank 'savings bank' > sberbank 'id.' > sberbankovskij 'related to a savings bank'

Some stumps such as kom- 'communist' and soc- 'socialist' are mostly found in historical expressions of the Soviet era. Others are still productive, also as part of newly coined formations, such as gos- 'state.RA', e.g.:

(22) goskorporacija < gosudarstvennaja korporacija 'state corporation (a type of legal entity in Russia introduced in 1999)'

Others are new:

(23) terakt < terrorističeskij akt [terrorist(ic) action] 'terror(ist) attack'

In addition, certain stumps such as polit- < političeskij 'political' which are known from the notorious designation politbjuro 'politburo', can also be found in more recent forms, such as (24):

(24) politkorrektnost' 'political correctness', politjumor 'political humor'

These stump compounds which are common in politics, administration, press etc., contrast with formations that have become part of the general language. Most of these compounds are more frequent than the underlying phrases (number of hits of formations in the nominative according to Yandex ${ }^{21}$ ):

(25a) roddom (7 m.) < rodil'nyj $\underline{\text { dom }}$ ( $2 \mathrm{~m}$.) [give birth/bear.A house] 'maternity clinic'; no corresponding stump compound (*rodklinika) of the less frequent and more prestigious naming rodil'naja klinika 'id.' is found, however.

(25b) zapčasti $(212 \mathrm{~m}$.$) < zapasnye časti (15 \mathrm{~m}$.) 'spare parts'

21 Yandex is the most frequently used Internet search engine in Russia. 


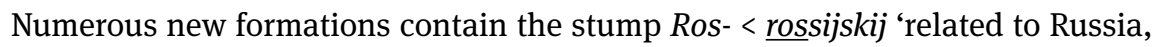
Russian governmental institutions, enterprises with state participation etc.', e.g. Rostelekom 'Rostelecom'. Ros- is, however, predominantly found in proper names that are based only on parts of multi-word names. In the following example Roscan be said to replace Federal'nyj 'federal':

(26) Rospotrebnadzor [Russ(ian) Consum(er) Supervision] = Federalnaja služba po nadzoru $v$ sfere zaščity prav potrebitelej i blagopolučija čeloveka

'Federal Service for Surveillance on Consumer Rights Protection and Human wellbeing. ${ }^{22}$

A similar formation principle is used for naming organizations or enterprises without an established multi-word designation to which the components might be related, $\mathrm{cf}$. (27):

Rosènergoatom (also RosÉnergoAtom)

a corporation running nuclear power stations in Russia

As proper names such coinings provide more "convenient" constructions, even when complex multi-word terms exist in parallel.

\subsubsection{Pragmatic and textual differences between phrasal nouns and corresponding shortened formations}

The differences between stump compounds and suffix formations with - $k a$ can be summarized as follows: Stumped compounds are generally used in the area of politics, administration and business. The underlying phrasal nouns, however, indicate a higher level of official status. A higher level of transparency is obtained with currently used stump compounds by not clipping the head. The clipped modifiers are less transparent than the respective word stem (which is retained in the deadjectival - $k a$ formations), but they relate to a thematically more clearly restricted range of designation. Frequency specification of stump compounds in Russian newspapers from the year 2014 can be found in Milan Albertin (2013/14:

22 Compounds such as Rostrud [Russ(ian) labor], Federal'naja služba po trudu i zanjatosti 'Federal Labor and Employment Service' are reminiscent of the old type Glavryba (cf. the examples cited by Isačenko 1958 in Section 1.1). 
76): state matters $35 \%$, military $15 \%$, occupations and functions $12 \%$, business $7 \%$, medicine $4 \%$ and other $14 \%$.

Stump compounds are generally formed “top down”, i.e. as planned designations. They are characterized by serial formation and - at least in present-day Russian - the clipped elements are only rarely homonymous. ${ }^{23}$ Stump compounding as a semi-official type of word formation is sometimes also used in ironic occasionalisms, cf. litnomenklatura 'literary nomenklatura' (from the 1990s) (Uluchanov/Belentschikow 2007: 290) or the name of the Russian heavy metal band Tjažmet < tiaželyj metall 'heavy metal', consciously aiming at a contrast, as in the past and sometimes even today this stump compound is found in the meaning 'heavy metallurgy' as part of the official name of respective companies.

Derivations with - $k a$ based on phrasal nouns are in general formed spontaneously and "from below", i.e. in oral communication. The preferred thematic areas are to be distinguished from those of stump compounds, cf. coll. kožanka 'leather jacket' < kožanaja kurtka, but not *kožkurtka (in contrast to the common stump compound kožizdelija < kožanye izdelija 'leather ware, leather goods').

The following example may summarize the above said. A Russian passport can be referred to as follows:

a) in official use with a multi-word expression and a corresponding acronym: obščegraždanskij zagraničnyj pasport (OZP) [civil international passport],

b) in semi-official use with a stump compound: zagranpasport,

c) everyday use prefers derivatives like zagranka or zagrannik,

d) a further variant - the clipped stem zagran as noun - is found in social slang.

Masini/Benigni (2012: 447) regard the formation of such shortened lexemes also as a strategy of a highly inflectional language "to 'morphologize' lexical items that are larger than a word".

23 There are, however, older formations where the stump kom refers to kommunističeskij 'communist (A)', komandir 'commander' and komitet 'committee', for instance. 


\section{On the relation between MWEs of the type "relational adjective + noun" and compounds}

\subsection{RA+N combinations compensating a lack of nominal compound types}

The preceding section has discussed the tendency of "morphologizing" word combinations. However, it is obvious that in Russian everyday speech there are also numerous relatively fixed designations of the type $[\mathrm{RA}<\mathrm{N}]+\mathrm{N}$ without shortened variants on - $k a$. These MWEs contrast with $\mathrm{N}+\mathrm{N}$ compounds in English and German (leaving calques out of consideration), e.g.

a) polevaja myš' 'field mouse' (but see suffixal polëvka 'vole'), vodjanaja ptica 'water bird',

b) utrennjaja smena 'morning shift' (but see suffixal utrennik 'morning performance'), nočnoj polet 'nightflight',

c) jabločnyj pirog 'apple pie', rapsovoe maslo 24 'rape oil' (see also parallel formations of the type $\mathrm{N}+\mathrm{Prep}+\mathrm{N}$, e.g. with the preposition $s$ 'with', $i z$ 'of, from'),

d) bannoe polotence 'bath towel', komp'juternye igry 'computer games' (see also parallel formations of the type $\mathrm{N}+\mathrm{Prep}+\mathrm{N}$, e.g. with the preposition dlja 'for').

The reservations that have been expressed about the listing of possible meaning relations between modifiers and non-deverbal heads of compounds (cf., e.g., Plag 2009: 150 with respect to English), may also hold for RA+N combinations. ${ }^{25}$ However, it is obvious that there are certain typical relations, depending on the semantics of the modifier and the head of the MWE, i.e. local and temporal $(a, b)$, purpose (c) or reference to the source or origin of what is referred to by the head (d).

Even if compounds can be formed, MWEs may be perceived as more canonical. This becomes evident from the persistence of $\mathrm{RA}+\mathrm{N}$ combinations alongside older compound calques as well as from the different ways of adapting of new English $\mathrm{N}+\mathrm{N}$ compounds and compound patterns.

24 Only occasionally the otherwise unknown/rare compound rapsomaslo [raps.LV.oil] is found in Internet forums.

25 Plag, for example, provides two interpretations of marble museum - 'a museum built with marble' and 'a museum in which marble objects are exihibited'. These can potentially also be found in the Russian mramornyj muzej $(\mathrm{RA}+\mathrm{N})$. Admittedly a search for muzej on the Internet typically renders associations with what is exhibited, cf. Mramornyj muzej v Mramornom dvorce 'The Marble museum in the Marble Palace (of Catherine the Great in Petersburg)'. 


\subsection{Compounds}

\subsection{1 "Classical" patterns $(\mathrm{N}+\mathrm{LV}+\mathrm{N})$ and parallel patterns $\left(\mathrm{RA}+\mathrm{N}, \mathrm{N}+\mathrm{N}_{\mathrm{GEN}}\right)$}

When dealing with Russian determinative compounds with $\mathrm{N}_{\text {STEM }}$ as modifier and non-derived head, it becomes obvious that their number is restricted. Compounds of the type $\mathrm{N}_{\text {STEM }}+[\mathrm{N}<\mathrm{V}]$ are much more productive. Although Grammatika-80 (Švedova 1980: 242) does not make such a distinction, examples such as zvukorežisser [sound.Lv.director] 'sound producer', pticefabrika 'poultry plant', chlebozavod [bread.Lv.plant] 'bakery plant' (next to RA+N chlebnyj zavod), gazoballon 'gas bottle' (more frequently RA+N gazovyj ballon), kino-teatr [cinema-theatre] 'cinema' can be assigned to the first group, expressing primarily purpose relations. The second group includes compounds like sen-o-uborka 'hay harvest', dač-e-vladelec 'dacha-owner', ovošč-e-chranilišče 'vegetable store', reflecting the argument structure of the verb that underlies the head.

These differences become also apparent in the form of Russian equivalents of English compounds. Russian equivalents of English formations with deverbal heads are more frequently compounds of the form $\mathrm{N}_{\mathrm{STEM}}+\mathrm{LV}+\mathrm{N}$ (or $\mathrm{N}+\mathrm{N}_{\text {GEN }}$ ) and less frequently $\mathrm{RA}+\mathrm{N}$ patterns. Russian equivalents of other English compounds are, however, for the most part of the type RA+N, cf. Table 2:

Table 2: Compounds and multi-word expressions in Russian

\begin{tabular}{lll}
\hline English & Russian & \\
\hline Compound N+N & Compound $\mathrm{N}+\mathrm{LV}+\mathrm{N}$ & Relational adjective $+\mathrm{N}$ or $\mathrm{N}+\mathrm{N}_{\mathrm{GEN}}$ \\
\hline (1) ship building & sudostroenie $(38 \mathrm{~m} .)^{26}$ & $\begin{array}{l}\text { sudovoe stroenie }(267) \\
\text { stroenie sudov }(3,000)\end{array}$ \\
\hline (2) ship repair & sudoremont $(13 \mathrm{~m})$. & $\begin{array}{l}\text { sudovoj remont }(940) \\
\text { remont sudov }(19 \mathrm{~m} .)\end{array}$ \\
\hline (3) ship owner & sudovladelec $(5 \mathrm{~m})$. & $\begin{array}{l}\text { sudovoj vladelec (sporadically) } \\
\text { vladelec sudna }(3 \mathrm{~m} .)\end{array}$ \\
\hline (4) ship mechanic & sudomechanik $(132,000)$ & $\begin{array}{l}\text { sudovoj mechanik }(5 \mathrm{~m} .) \\
\text { mechanik sudov }(2,000)\end{array}$ \\
\hline
\end{tabular}

26 Here and subsequently: occurrences in the nominative/accusative in Yandex (January and November 2017). 


\begin{tabular}{lll}
\hline English & Russian & \\
\hline Compound $\mathrm{N}+\mathrm{N}$ & Compound $\mathrm{N}+\mathrm{LV}+\mathrm{N}$ & Relational adjective $+\mathrm{N}$ or $\mathrm{N}+\mathrm{N}_{\mathrm{GEN}}$ \\
\hline (5) ship-broker & sudobroker (14) & $\begin{array}{l}\text { sudovoj broker }(28 \mathrm{~m} .) \\
\text { broker sudov (108) }\end{array}$ \\
\hline (6) shipboard & - & $\begin{array}{l}\text { sudovoj bort (368) } \\
\text { bort sudna (7 m.) }\end{array}$ \\
\hline (7) ship anchor chain & - & $\begin{array}{l}\text { jakornaja cep' sudna } \\
{[\mathrm{RA}+\mathrm{N}]+\mathrm{N}_{\mathrm{GEN}}}\end{array}$ \\
\hline
\end{tabular}

Besides, we also have to consider that numerous English MWEs and compounds correspond to regular suffixal expressions in Russian, as in the case of a) denominal personal nouns: parket-čik 'parquet-layer' < parket 'parquet', ryb-ak 'fisherman' < ryba 'fish', splet-nik 'scandalmonger' < spletni 'rumors', šachmat-ist 'chess player' < šachmaty 'chess', and b) place nouns: vinograd-nik 'wine yard' < vinograd 'grapes; vine', cvet-nik 'flower garden' < cvet(y) 'flower(s)', spal'nja 'sleeping-room' < spat'sleep', etc.

\subsection{2 $\mathrm{N}+\mathrm{N}$ compounds without linking vowel}

Numerous older borrowed $\mathrm{N}+\mathrm{N}$ compounds (without linking vowel) as a rule have $\mathrm{RA}+\mathrm{N}$ equivalents, which sometimes are more frequent than the compound, $\mathrm{cf}$.:

(28) dizel'-motor (15,000) 'diesel engine' vs. dizel'nyj motor (13 m.) 'id.'; note, however, the use of the compound in names of business and the formation of a new common noun according to the structure $\mathrm{N}+\mathrm{N}$ : dizel-servis "Dizel'-Motor" 'diesel-service "Diesel-Engine”' (cf. Section 4.2.3), vakuumkamera $(45,000)$ 'vacuum chamber' vs. vakuumnaja kamera (25 m.) 'id.'

A similar relationship exists between some recent compounds (partial calques based on the English $\mathrm{N}+\mathrm{N}$ model) and formations consisting of $\mathrm{RA}+\mathrm{N}$. In the case of

(29) demping ceny ‘dumping prices’ vs. dempingovye ceny [dumping.RA prices]

the reasons for the preference of $\mathrm{RA}+\mathrm{N}$ are to be found in the enhanced syntactic availability or, more precisely, transparency. The ratio of the borrowed compound is considerably lower than the phrase in oblique cases, cf. Russian dative pl. po 
demping cenam 'goods at dumping prices' $(1,240)$ vs. po dempingovym [RA] cenam 'id.' (181,000), prepositive case pl. o demping cenach (not attested) 'about dumping prices' vs. o dempingovych cenach 'id.' (900). The genitive plural demping cen is obviously entirely avoided due to its homonymy with $\mathrm{N}+\mathrm{N}_{\mathrm{GEN}}$ [dumping prices. GEN] 'price dumping'.

In addition to parallel formations of the patterns $\mathrm{N}+\mathrm{N}$ (marketing direktor 'marketing director') and $\mathrm{RA}+\mathrm{N}$ (marketingovyj direktor) alternative patterns of the form $\mathrm{N}+\mathrm{N}_{\mathrm{GEN}}$ (director martekinga) and $\mathrm{N}+\mathrm{Prep}+\mathrm{N}$ (direktor po marketingu 'director of marketing') occur frequently, in particular with respect to professional titles and functional descriptions.

There are, however, numerous new $\mathrm{N}+\mathrm{N}$ compounds, including compounds with abbreviated modifiers, that do not or only occasionally have $\mathrm{RA}+\mathrm{N}$ “competitors":27

(30a) biznes-vstreča 'business meeting', biznes-pravo 'business law', internet-opros 'internet survey', internet-magazin 'internet shop'

(30b) IT-specialist, IT-uslugi 'IT services' (IT can be spelled in latin script, but it is more frequently rendered in Cyrillic.)

According to Benigni/Masini (2009: 179), a criterion for the productivity of $\mathrm{N}+\mathrm{N}$ patterns in contemporary Russian is the fact that "not only loan words, but also native words occur in this pattern, especially in head position”. N+N compounds are also the topic of an article by Kapatsinski/Vakareliyska (2013). According to the authors these new $\mathrm{N}+\mathrm{N}$ compounds can be found in certain thematic areas, such as business (cholding kompanija 'holding company'), politics and media (press-diskussija 'press discussion'), music and entertainment (lajting chudožnik 'lighting artist'28), commerce, technology, computers and the Internet (see above), medicine and health, fashion and sexuality (ibid.: 71).

$\mathrm{N}+\mathrm{N}$ compounds are also commonly used as names for businesses and events, e.g., Nogti-Servis 'Nail Service' (name of a manicure salon), etc. Kapatsinski/Vakareliyska (ibid.: 78) emphasize that this formation type "appears to have developed a distinct connotation: that is, it is not pragmatically synonymous

27 The preference for another compound pattern over MWEs with RA has been evident for some time in the formation of compounds with neo-classical modifiers, or, more generally, internationalisms, e.g., tele- (< televizionnyj) 'TV-, television-', cf. telezritel' (NOM.SG 50 m.) 'TV-viewer' vs. televizionnyj zritel' (NOM.sG 1,000).

28 Cf. also the direct, only grammatically adapted borrowing (here: NOM.PL) lajting \& šejding supervajzery 'lighting and shading supervisors'. 
with some other Russian constructions" (in accordance with the No Synonymy Principle as postulated in Construction Grammar). Whereas a possible stump compound like gorzal from gorodskoj zal [city.RA hall] 'civic hall' would have the connotation of a "Soviet holdover", the new N+N compound Krokus Siti Choll 'Crocus City Hall' (opened in 2009 near Moscow) "has a cosmopolitan, western association" (p. 81). In the case of other patterns that were already used in the Soviet era such as $\mathrm{N}_{\text {Toponym }}+\mathrm{N}$ (e.g. Tulaugol 'Tulacoal', name of a coal trust in the district of Tula), the pattern is retained but newly filled, e.g. Tulabar. Here, the "difference in connotations can be plausibly attributed to the interaction between the structure of the expression and the individual words that enter the structure, rather than to the structure per se" (Kapatsinski/Vakareliyska 2013: 81). By means of the new filling the pattern itself gains "a new prestige".

\subsection{3 $\mathrm{N}+\mathrm{N}$ compounds as proper names}

As has been shown by some of the examples above, the idea that $\mathrm{N}+\mathrm{N}$ compounds (without linking vowel) are on the increase is also suggested by their frequent occurrence in proper nouns, such as company names (e.g. Ivent-Ëkspert 'event expert' as the name of an agency for marketing solutions). Such names often adopt English patterns, which are also used for common nouns in English everyday speech. This is however not the case in Russian:

Proprial formations

Non-proprial formations

(arranged by the frequency of occurrence of the respective formation type: $\mathrm{N}+\mathrm{N}_{\text {GEN }}, \mathrm{RA}+\mathrm{N}, \mathrm{N}+\mathrm{N}$ with linking vowel $o$ or $e$ )

Gazéksport éksport gaza, gazovyj èksport, gazoèksport

'Gas export'

Mebel'import

Mebel'Import ${ }^{29}$

Mebel' Import

'Furniture import'

import mebeli, mebel'nyj import; a non proprial compound ${ }^{\star}$ mebeleimport is not evidenced

Similar observations apply to names of Internet domains, e.g. Vodosport (with linking vowel) 'water sports (equipment)' which has not (yet) been established as

29 It is striking that in many of these newly coined formations the second component is capitalized. 
part of the general vocabulary, in contrast to the common appellative construction vodnyj sport (water.RA+N). As a common noun vodosport occurs only sporadically in Yandex, ${ }^{30}$ as in the following example, possibly in analogy to other types of sports which are mentioned in the context, with international clipped initial components:

(32) Nado vernut'sja v motosport, velosport. Vodosport vsegda byl v Murome populjaren. ${ }^{31}$

'We have to return to motor sports, to cycle sports. Watersports were always popular in Murom.'

Vodopolo (in standard language $\mathrm{RA}+\mathrm{N}$ vodnoe pole) 'water polo' and vodolyži (in standard language vodnye lyži 'water ski') are also found as common nouns in Internet texts, however with a linking vowel (!), i.e. not *Voda sport. (In standard language the stem vod- 'water' is found only in compounds with a deverbal head, e.g. vod-o-snabženie 'water supply'.) It remains to be seen whether - under the influence of certain text types - the pattern $\mathrm{N}_{\text {STEM }}+\mathrm{LV}+\mathrm{N}$ will also occur with those implicit meaning relations that have only been used in $\mathrm{RA}+\mathrm{N}$ combinations so far (cf. Section 4.1).

\section{Conclusion}

After a short overview of contributions of Slavic studies on the topic of the present volume this chapter explored some of the relations between non-idiomatic determinative MWEs/phrasal nouns and one-word designations in Russian, viz.:

a) MWEs and a (specific Slavic) type of condensed one-word designations,

b) MWEs/phrasal nouns und stump compounds,

c) MWEs/phrasal nouns and nominal compounds.

Particular emphasis was placed on functional-stylistic and pragmatic differences of referentially identical formations with different structures (cf. Section 3.2 on the relationship of MWEs/phrases and one-word designations, based on several shortening strategies). While suffixal derivations from MWEs/phrases can also be

30 There we also find vodopolo (in standard language $\mathrm{RA}+\mathrm{N}$ vodnoe pole) 'water polo', vodolyži (in standard language vodnye lyži) 'water ski'.

31 https://kachevan.livejournal.com/tag/ \%D1 \%81 \%D0 \%BF \%D0 \%BE \%D1 \%80 \%D1 \%82 (last access: 30.4.2018). 
found in other Slavic languages, stump compounds - as common names - are largely a specific characteristic of Russian.

With respect to nominal compounding, the chapter has focused on determinative compounds of the type $\mathrm{N}_{\text {STEM }}+\mathrm{LV}+\mathrm{N}$-Type and the $\mathrm{N}+\mathrm{N}$ type (without linking vowel) and parallel MWEs with the structure $\mathrm{N}+\mathrm{N}_{\mathrm{GEN}}$ or $\mathrm{RA}+\mathrm{N}$. (Relational adjectives are today still essential for the integration of numerous borrowed compounds as MWEs). In case of frequently occurring modifiers of $\mathrm{N}+\mathrm{N}$ compounds a decrease of parallel $\mathrm{RA}+\mathrm{N}$ formations can be observed. The Russian $\mathrm{N}+\mathrm{N}$ type was already determined by borrowings in earlier times. In present-day language it is spreading due to the influence of English, since these compounds are no longer restricted to certain thematic areas. An increasing tendency to use the pattern also with non-borrowed words (particularly as head) can be observed. In addition, the spread of the $\mathrm{N}+\mathrm{N}$ pattern is supported by the frequent use as proper names (cf. Mebel' Import 'furniture import') which is however still competing with appellative MWEs (import mebeli 'import of furniture').

Analyses of recent developments in the vocabulary of Russian often point to two opposing tendencies (cf. also Masini/Benigni 2012: 447): on the one hand, the increasing tendency towards analyticity (cf. the productive formation of MWEs/phrasal nouns), and, on the other, the persisting tendency towards synthesis (cf. the $-k a$ formations derived from MWEs as well as the "condensation of complex nominals" in Slavic languages as mentioned in the introduction.)

The joint reflection on various naming procedures in consideration of their functional differences was determined especially by the onomasiologically orientated research of Slovak and Czech linguists and adopted in Russian research in the 1970s (cf. Serebrennikov (ed.) 1977a, 1977b). However, the interaction between different naming procedures has been considered in the Russian grammars only in the case of MWEs that form the basis of derivations or compounds and are being clipped or shortened. An appropriate theoretical framework for the common consideration of the various procedures is provided by Construction Grammar, and in particular Construction Morphology (Booij 2010), which is based on the fundamental assumption that there is no strict distinction between word formation and/or the lexicon on the one hand and syntax on the other hand. It seems that, for this reason, the simultaneous and in principle equal occurrence of morphological and syntactic naming procedures, as evidenced in this chapter for Russian, can be captured adequately by constructional frameworks. We therefore conclude by referring to Construction Grammar based analyses of compounds and MWEs in Russian and other Slavic languages in Benigni/Masini (2009), Masini/Benigni (2012), Cetnarowska (in this volume) as well as analyses on other languages in the volume at hand (amongst others Booij, this volume, Masini, this volume, Van Goethem and Amiot, this volume, and Schlücker, this volume). 


\section{References}

Alekseenko, Michail A./Belousova, Tatjana P./Litvinnikova, Ol'ga I. (eds.) (2003): Slovar' otfrazeologičeskoj leksiki sovremennogo russkogo jazyka. Moskva: Azbukovnik.

Arcordia, Giogio Francesco/Montermini, Fabio (2013): Are reduced compounds compounds? Morphological and prosodic properties of reduced compounds in Russian and Mandarin Chinese. In: Renner, Vincent/Maniez, François/Arnaud, Pierre (eds.): Cross-disciplinary perspectives on lexical blending. Berlin/Boston: De Gruyter. 93-114.

Belošapkova, Vera A. (ed.) (1989): Sovremennyj russkij jazyk. $2^{\text {nd }}$ ed. Moskva: Vysš. Škola.

Benigni, Valentina (2012): I binomi coordinativi in russo: un'analisi costruzionista. In: mediAzioni 13. Internet: www.mediazioni.sitlec.unibo.it/images/stories/PDF_folder/ document-pdf/slavistica2012/01_benigni.pdf (last access: 1.9.2017).

Benigni, Valentina/Masini, Francesca (2009): Compounds in Russian. Lingue e Linguaggio VIII, 2. 171-193.

Benigni, Valentina/Masini, Francesca (2010): Nomi sintagmatici in russo. In: Studii Slavistici VII. 145-172.

Billings, Loren A. (1998): Morphology and Syntax. Delimiting stump compounds in Russian. In: Booij, Gert/Ralli, Angelij/Scalise, Sergio (eds.): Proceedings of the First Mediterranean Morphology Meeting. Patras: University of Patras. 99-110.

Booij, Geert E. (2010): Construction morphology. Oxford/New York: Oxford Univ. Press.

Comrie, Bernhard/Stone, Gerald (1978): The Russian language since the revolution. Oxford: Clarendon Press.

Comrie, Bernhard/Stone, Gerald/Polinsky, Maria (1996): The Russian language in the twentieth century. 2nd ed. Oxford: Clarendon Press.

Dokulil, Miloš (1962): Tvoření slov v češtině. Vol. 1: Teorie odvozování slov. Praha: Nakl. Československé Akad. Věd.

Droga, Marina A. (2010): Sostavnye naimenovanija v russkom jazyke. Belgorod: Belgorodskij Gosudarstvennyj Universitet. Internet: http://cheloveknauka.com/v/332425/d\#?page=1 (last access: 11.9.2018).

Isačenko, Aleksandr V. (1958): K voprosu o strukturnoj tipologii slovarnogo sostava slavjanskich literaturnych jazykov. In: Slavia 27. 334-352.

Kapatsinski, Vsevolod/Vakareliyska, Cynthia M. (2013): [N[N]] compounds in Russian. A growing family of constructions. In: Constructions and Frames 5, 1. 69-87.

Kuchař, Jaroslav (1963): Základní rysy struktur pojmenování (Basic features of naming structures). In: Slovo a slovesnost 24, 2. 105-114. Internet: http://sas.ujc.cas.cz/archiv. php?art=1230 (last access: 11.9 .2018$)$.

Martincová, Olga (2015): Multi-word expressions and univerbation in Slavic. In: Müller, Peter 0. et al. (eds.). 742-757.

Masini, Francesca/Benigni, Valentina (2012): Phrasal lexemes and shortening strategies in Russian. The case for constructions. In: Morphology 22. 417-451.

Milan Albertin, Isabella (2013/14): Analisi linguistica dei composti troncati in russo e del loro utilizzo nel linguaggio giornalistico. (MA thesis). Università Ca'Foscari Venezia. Internet: http://dspace.unive.it/bitstream/handle/10579/6112/987901-1193458.pdf?sequence=2 (last access: 1.11.2017).

Mokijenko, Walerij/Walter, Harry (2008): Leksičeskie i frazeologičeskie neologizmy: obščee i različnoe. In: Mokijenko, Walerij/Walter, Harry (eds.): Komparacja systemów i 
funkcjonowania wspótczesnych języków stowiańskich. Vol. 3: Frazeologia. Opole: Wydawn. Uniw. Opolskiego. 101-108.

Müller, Peter O. et al. (eds.) (2015): Word-formation. An international handbook of the languages of Europe. Vol. 1. (= Handbooks of Linguistics and Communication Science (HSK) 40.1). Berlin/Boston: De Gruyter.

Nagórko, Alicja (2014): Diminutiva/Augmentativa. In: Kempgen, Sebastian et al. (eds.): Die slawischen Sprachen. Ein internationales Handbuch zu ihrer Struktur, ihrer Geschichte und ihrer Erforschung. Vol. 1. Berlin/New York: De Gruyter. 782-792.

Neef, Martin (2015): Synthetic compounds in German. In: Müller, Peter O. et al. (eds.). 582-593. Ološtiak, Martin (ed.) (2015): Viacslovné pomenovania v slovenčine. Prešov: FF PU v Prešove. Plag, Ingo (2009): Word-formation in English. $5^{\text {th }}$ ed. Cambridge, UK: Cambridge University Press.

Šanskij, Nikolaj M. ([1963] 1985): Frazeologija sovremennogo russkogo literaturnogo jazyka. Moskva.

Serebrennikov, Boris A. (ed.) (1977a): Jazykovaja nominacija. Obščie voprosy. Moskva: Izd. Nauka.

Serebrennikov, Boris A. (ed.) (1977b): Jazykovaja nominacija. Vidy naimenovanija. Moskva: Izd. Nauka.

Steffens, Doris/Nikitina, Olga (2014): Deutsch-russisches Neologismenwörterbuch. Neuer Wortschatz im Deutschen 1991-2010. Mannheim: Inst. für Deutsche Sprache.

Švedova, Natal'ja Ju. (ed.) (1980): Russkaja grammatika. Moskva: Izd. Nauka.

Uluchanov, Igor' S./Belentschikow, Renate (2007): Russko-nemeckij slovar' novych slov. Moskva: Izdat. Centr Azbukovnik.

Vinogradov, Viktor V. (1946): Osnovnye ponjatija russkoj frazeologii kak naučnoj discipliny. Leningrad.

Wälchli, Bernhard (2015): Co-compounds. In: Müller, Peter O. et al. (eds.). 707-727. 